\title{
Morphological Variation of Malayopython reticulatus (Schneider, 1801) from Several Population in Indonesia
}

\author{
Luhur Septiadi ${ }^{1}$, M. Fathoni ${ }^{2}$, Berry Fakhry Hanifa ${ }^{1}$, Amir Hamidy ${ }^{3}$ \\ ${ }^{1}$ Department of Biology, State Islamic University of Maulana Malik Ibrahim, Malang 65145, Indonesia \\ ${ }^{2}$ Department of Biology, Faculty Mathematics and Natural Sciences, Brawijaya University, Malang 65145, \\ Indonesia \\ ${ }^{3}$ Laboratory of Herpetology, Zoology Division, Research Center for Biology, Indonesian Institute of Sciences, \\ Cibinong 16912, Indonesia
}

Article history:

Submission April 2019

Revised August 2019

Accepted August 2019

*Corresponding author:

E-mail: luhur.septiadi@gmail.com

\begin{abstract}
Reticulated python (Malayopython reticulatus) is a widely distributed snake covering throughout Southeast Asia and almost all of Indonesia archipelago and divided into several subspecies based on morphological variation and its locality. Morphological variation data of $M$. reticulatus from Indonesia population has never been done thoroughly. This study aims to determine the morphological variations based on 21 meristic and 3 morphometric characters from several populations in Indonesia. The data was collected from the Museum Zoologicum Bogoriense (MZB) Cibinong, Indonesia and other additional collections that are carried out from June to July 2018 and then analyzed by Principal Component Analysis (PCA) to determine the population grouping. The result showed a high variation on the scale range of anterior prefrontal, posterior prefrontal, frontal, parietal, preocular, postocular, loreal, temporal, upper labial, lower labial, and dorsal scales. Ventral and subcaudal scales in male and female specimens show high variation in the total scale count, the ratio comparison of tl: SVL measurement, indicated the sexual dimorphism. Prefrontal (anterior-posterior) and frontal scales show high variation and difficult to distinguish between each locality at the subspecies level and suggest it to be intra-specific variation. There is no significant grouping were found between populations from data on morphological variations.
\end{abstract}

Keywords: Malayopython reticulatus, morphological variation, intra-specific variation, Indonesia

\section{Introduction}

Reticulated python (Malayopython reticulatus, Schneider, 1801) is a large constrictor snake of Pythonidae family that's widely distributed throughout Southeast Asia and almost all of Indonesia archipelago [1]. The widespread of this species give rises to morphological and genetic variations given by many factors such as population isolation, geographical barrier, evolutionary process and also the influence of the environment and its habitat. The variation is then used as a comparing reference (diagnostic character) for distinguishing a species [2]. Morphological variations are observed based on phenetic characters includ- ing color patterns, specific characteristics of species, patterns, and body size ratios, and meristical characters such as scale ranges [3]. These variations are further analyzed, to determine the existence of significant differences between species or sub-species.

M. reticulatus is divided into 3 subspecies based on its locality, namely $M$. reticulatus reticulatus (Greater Sunda), M. reticulatus saputrai (Selayar Island), and M. reticulatus jampeanus (Tanahjampea Island). Two subspecies recently recognized ( $M$. reticulatus saputrai and M. reticulatus jampeanus) by having a few specific morphological variations that only subspecies posse- 
Table 1. M. reticulatus specimens observed from several populations in Indonesia, collection of Museum Zoologicum Bogoriense (MZB) LIPI and several additional specimens

\begin{tabular}{|c|c|c|c|}
\hline No. & ID. Number & Population & Locality \\
\hline 1. & MZB. Ophi. 5287 & & Dalas, Southern Lampung \\
\hline 2. & MZB. Ophi. 201 & & F. Krakatau Island, Lampung \\
\hline 3. & MZB. Ophi. 4680 & & F. Krakatau Island, Lampung \\
\hline 4. & MZB. Ophi. 2412 & sumatera & Saraya, Southeast Aceh \\
\hline 5. & MZB. Ophi. 1692 & & Tiwi River, Kota Tua, Riau \\
\hline 6. & MZB. Ophi. 2192 & & Bengkalis, Riau \\
\hline 7. & MZB. Ophi. 2936 & & Pangandaran, West Java \\
\hline 8. & MZB. Ophi. 197 & & Cikopo, West Java \\
\hline 9. & MZB. Ophi. 4681 & Jawa & Cikopo, West Java \\
\hline 10. & MZB. Ophi. 5286 & & Malang, East Java \\
\hline 11. & MZB. Ophi. 2152 & & Hilir Village, Southern Barito, Central Kalimantan \\
\hline 12. & MZB. Ophi. 1906 & & Pontianak, West Kalimantan \\
\hline 13. & MZB. Ophi. 1457 & & Banjarmasin, South Kalimantan \\
\hline 14. & MZB. Ophi. 5884 & Kalımantan & Lumbis River, Nunukan, North Kalimantan \\
\hline 15. & MZB. Ophi. 3020 & & TNKM Kragan, Nunukan, East Kalimantan \\
\hline 16. & MZB. Ophi. 3121 & & Marang, Sangkulirang, East Kalimantan \\
\hline 17. & MZB. Ophi. 5785 & NTB & Kawinda Toi, Sumbawa Island \\
\hline 18. & MZB. Ophi. 5589 & & Saunulu, Central Maluku \\
\hline 19. & MZB. Ophi. 1951 & & Saunulu, Central Maluku \\
\hline 20. & MZB. Ophi. 4481 & & North Halmahera, North Maluku \\
\hline 21. & MZB. Ophi. 4482 & Maluku & North Halmahera, North Maluku \\
\hline 22. & MZB. Ophi. 194 & & West Seram Island, Maluku \\
\hline 23. & MZB. Ophi. 200 & & Timor Island, Maluku \\
\hline 24. & MZB. Ophi. 1558 & & Anca Danau Lindu, Central Sulawesi \\
\hline 25. & MZB. Ophi. 3221 & & Dampala River, Morowali, Central Sulawesi \\
\hline 26. & MZB. Ophi. 2895 & & Goa Keramat, Tawaeli, Donggala, Central Sulawesi \\
\hline 27. & MZB. Ophi. 1762 & & Tomodo, Lindu Valley, Central Sulawesi \\
\hline 28. & MZB. Ophi. 2297 & & Marowo, Tojo Una-Una, Central Sulawesi \\
\hline 29. & MZB. Ophi. 1657 & & Jompi, Raha, Muna Island, Southeast Sulawesi \\
\hline 30 . & MZB. Ophi. 4682 & & Jompi, Raha, Muna Island, Southeast Sulawesi \\
\hline 31. & MZB. Ophi. 2041 & Sulawesi & Latimojong Mountain, Luwu, South Sulawesi \\
\hline 32. & MZB. Ophi. 3436 & & Selayar Island, Southern Sulawesi Arhipelago \\
\hline 33. & MZB. Ophi. 3223 & & Tanahjampea Island, Southern Sulawesi Archipelago \\
\hline 34. & MZB. Ophi. 3437 & & Kalaotoa Island, Southern Sulawesi Archipelago \\
\hline 35. & S.Voucher. 020 & & Karompa Island, Southern Sulawesi Archipelago \\
\hline 36. & S.Voucher. 021 & & Kalaotoa Island, Southern Sulawesi Archipelago \\
\hline 37. & S.Voucher. 022 & & Kalaotoa Island, Southern Sulawesi Archipelago \\
\hline 38. & S.Voucher. 023 & & Madu Island, Southern Sulawesi Archipelago \\
\hline
\end{tabular}

ssed from certain locality [4]. These differences are based on the shape of the anterior-posterior prefrontal scales, yet are still confused to inclusively categorizes it as geographical or intraspecific variations, also as diagnostic characters. Thus, examining more specimens of $M$. reticulatus from several population in Indonesia is needed.

Therefore, we present an overview of morphological characters of $M$. reticulatus to address several problems, to wit: 1) the tendency of other morphological characters from several of $M$. reticulatus populations, 2) to verifying the diagnostic characters of $M$. reticulatus especially on subspe- cies level, 3) the grouping of $M$. reticulatus population in Indonesia.

\section{Material and Methods Specimens observation}

All of 38 specimens of $M$. reticulatus from several populations in Indonesia were obtained from the collection of the Museum Zoologicum Bogoriense (MZB) that are observed during JulySeptember 2018 and few additional specimens that are collected on July - Agustus 2013 and April - May 2014 (Table 1). Morphological variations were observed by meristic and morphometric 

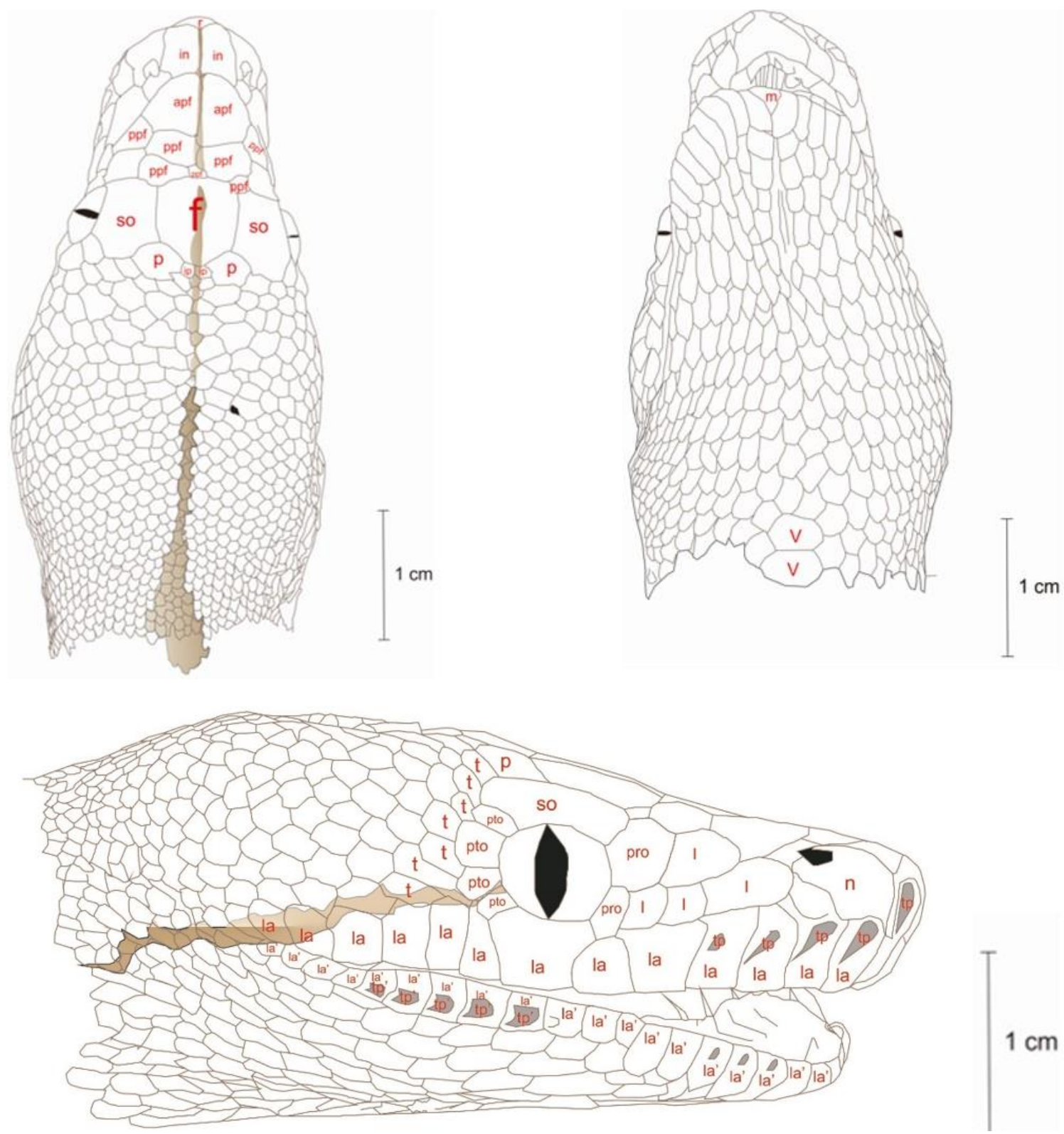

Figure 3. Meristical character on head scalation of M. reticulatus specimens that are observed. Abbrevation as follows: rostral (r), internal (i), anterior prefrontal (apf), posterior prefrontal (ppf), frontal (f), supraocular (so), parietal (p), interparietal (ip), preocular (pro), postocular (pso), loreal (l), temporal (t), upper labial (la), upper labial contacting orbit (lao), lower labial (la'), anterior upper thermal pits (tp), posterior lower thermal pits (tp'), mental (m), ventral (v). Scale bars $=1 \mathrm{~cm}$. (illustrated by Luhur Septiadi).

characters.

\section{Measurement of meristic, morphometric charac- ters, and analysis}

Morphometric characters are observed by 3 characters, as follows: a total of length (ToL), tail length (tl), and snout-vent length (SVL). Then, 21 meristic characters observed by scales counting, as follows: rostral (r), internasal (i), anterior prefrontal (apf), posterior prefrontal (ppf), frontal (f), su- praocular (so), parietal (p), interparietal (ip), preocular (pro), postocular (pso), loreal (l), temporal $(\mathrm{t})$, upper labial (la), upper labial contacting orbit (lao), lower labial (la'), anterior upper thermal pits (tp), posterior lower thermal pits (tp'), mental (m), dorsal midbody scales (d), ventral (v), and subcaudal (sc) (Figure 1), the characters used are according to Auliya [4] with standard measurement and scale counting following Lilywhite \& Wray [5]. Male and female specimens were differenti- 
Table 2. Measurement of meristic characters and morphometric ratios of M. reticulatus $\left(o^{\star}=14\right.$, 우 $\left.=24\right)$.

\begin{tabular}{|c|c|c|c|c|c|c|c|c|c|c|c|}
\hline \multirow{3}{*}{ Characters } & \multicolumn{11}{|c|}{ Population } \\
\hline & \multicolumn{2}{|c|}{ Sumatera } & \multicolumn{2}{|c|}{ Jawa } & \multicolumn{2}{|c|}{ Kalimantan } & \multirow{2}{*}{$\begin{array}{c}\text { NTB } \\
\hat{0} \\
(\mathrm{n}=1)\end{array}$} & \multicolumn{2}{|c|}{ Maluku } & \multicolumn{2}{|c|}{ Sulawesi } \\
\hline & $\begin{array}{c}\hat{0} \\
(\mathrm{n}=1)\end{array}$ & $\begin{array}{c}\text { P } \\
(\mathrm{n}=5)\end{array}$ & $\begin{array}{c}\hat{0} \\
(\mathrm{n}=1)\end{array}$ & $\begin{array}{c}9 \\
(\mathrm{n}=3)\end{array}$ & $\begin{array}{c}\hat{0} \\
(n=2)\end{array}$ & $\begin{array}{c}9 \\
(\mathrm{n}=4)\end{array}$ & & $\begin{array}{c}\hat{0} \\
(\mathrm{n}=4)\end{array}$ & $\begin{array}{c}\text { P } \\
(\mathrm{n}=2)\end{array}$ & $\begin{array}{c}\hat{0} \\
(\mathrm{n}=5)\end{array}$ & $\begin{array}{c}q \\
+ \\
(n=10)\end{array}$ \\
\hline $\mathbf{r}$ & 1 & 1 & 1 & 1 & 1 & 1 & 1 & 1 & 1 & 1 & 1 \\
\hline $\mathbf{i}$ & 2 & 2 & 2 & 2 & 2 & 2 & 2 & 2 & 2 & 2 & 2 \\
\hline apf & 2 & $2-4$ & 2 & 2 & 2 & 2 & 2 & 2 & 2 & $2-3$ & 2 \\
\hline ppf & 7 & $6-10$ & 9 & $7-8$ & 8 & $7-8$ & 8 & $5-9$ & 6 & $1-8$ & $4-9$ \\
\hline f & 1 & $1-2$ & 2 & $1-2$ & 2 & $1-2$ & 1 & $1-2$ & 1 & 1 & $1-2$ \\
\hline so & 2 & 2 & 2 & 2 & 2 & 2 & 2 & 2 & 2 & 2 & 2 \\
\hline p & 2 & $2-3$ & 2 & 2 & 2 & 2 & 2 & 2 & $2-3$ & 2 & 2 \\
\hline ip & 1 & $2-3$ & 1 & $3-5$ & 2 & $2-4$ & 2 & $1-3$ & $2-3$ & $1-2$ & $1-3$ \\
\hline pro & 2 & 2 & 2 & 2 & 2 & $2-3$ & 2 & 2 & 2 & 2 & 2 \\
\hline pso & $2-4$ & 4 & 3 & 4 & $3-5$ & $3-4$ & 4 & $2-4$ & 3 & $2-4$ & $2-4$ \\
\hline 1 & 3 & $3-5$ & 5 & $4-5$ & $2-4$ & $2-6$ & 4 & $3-4$ & 4 & $2-6$ & $3-4$ \\
\hline $\mathbf{t}$ & $4-5$ & $6-8$ & 7 & $6-7$ & $7-8$ & $6-8$ & $6-7$ & $5-7$ & $5-7$ & $5-7$ & $4-8$ \\
\hline $\mathbf{L a}$ & 14 & $13-14$ & 13 & $13-14$ & 14 & $12-13$ & 13 & $12-14$ & $13-14$ & $12-15$ & $11-13$ \\
\hline Lao & 7 & 7 & 7 & 7 & $7-8$ & 7 & 7 & 7 & 7 & $7-8$ & $6-8$ \\
\hline $\mathbf{l a}^{\prime}$ & 22 & $21-23$ & $21-22$ & $21-23$ & $22-24$ & 21 & 22 & $21-22$ & 22 & $19-25$ & $19-24$ \\
\hline Tp & 5 & $5-6$ & 5 & 5 & 5 & 5 & 5 & 5 & 5 & $4-6$ & 5 \\
\hline tp' & 6 & $5-6$ & 5 & 5 & 6 & 5 & 5 & 5 & 5 & $5-7$ & $5-7$ \\
\hline $\mathbf{m}$ & 1 & 1 & 1 & 1 & 1 & 1 & 1 & 1 & 1 & 1 & 1 \\
\hline d & 66 & $65-76$ & 66 & $61-77$ & 73-74 & $63-72$ & 69 & $67-77$ & $78-69$ & $67-90$ & $66-87$ \\
\hline $\mathbf{v}$ & 319 & $\begin{array}{c}310- \\
319\end{array}$ & 320 & $\begin{array}{c}301- \\
311\end{array}$ & $\begin{array}{c}312- \\
320\end{array}$ & $\begin{array}{c}316- \\
318\end{array}$ & 314 & $\begin{array}{l}284- \\
322\end{array}$ & $\begin{array}{c}320- \\
333\end{array}$ & $\begin{array}{c}300- \\
343\end{array}$ & $\begin{array}{l}294- \\
341\end{array}$ \\
\hline Sc & 89 & $\begin{array}{l}87- \\
100 \\
\end{array}$ & 94 & $87-93$ & $89-95$ & $87-96$ & 96 & 84-91 & $90-95$ & 87-94 & 83-94 \\
\hline tl:Tol & $0.17: 1$ & $0.14: 1$ & $0.14: 1$ & $0.12: 1$ & $0.14: 1$ & $0.13: 1$ & $0.14: 1$ & $0.14: 1$ & $0.12: 1$ & $0.13: 1$ & $0.12: 1$ \\
\hline SVL:Tol & 0.83:1 & $0.86: 1$ & $0.86 ; 1$ & $0.88: 1$ & $0.86: 1$ & $0.87: 1$ & $0.86: 1$ & $0.86: 1$ & $0.88: 1$ & $0.86: 1$ & $0.87: 1$ \\
\hline tl:SVL & $0.20: 1$ & $0.16: 1$ & $0.16: 1$ & $0.14: 1$ & $0.16: 1$ & $0.15: 1$ & $0.16: 1$ & $0.16: 1$ & $0.13: 1$ & $0.15: 1$ & $0.14: 1$ \\
\hline
\end{tabular}

ated to avoid bias due to sexual dimorphism on snakes, ToL, tl, SVL are converted into ratio. The results of morphometric and meristic character measurement were compared with previous studies. The data were further analysed using Principal Component Analysis (PCA), which compared the biggest variance (PC) from the data available.

\section{Results and Discussion \\ Morphological characters of M. reticulatus from several population}

The analysis showed the high variation on the scale range of anterior prefrontal, posterior prefrontal, frontal, parietal, preocular, postocular, loreal, temporal, upper labial, lower labial, and dorsal, ventral and subcaudal scales (Table 2). The obtained meristic character shows the intraspecific variations of the total number of scales that vary between specimens from several populations. The varying number of scales might be correlated to habitat use and environmental conditions that cause adaptation. This adaptation is done to pre- vent excess water loss in the body. A large number of scales might indicate habitats with high humidity, whereas fewer scales might indicate a drier habitat [6]. Reduction of dorsal scales might also be affected by the development of the cutaneous muscle system and cost-cutaneous muscles located below the skin as a result of the evolution of rectilinear locomotion [7].

Meristic characters do not show the sexual dimorphism based on the number of ventral and subcaudal scales due to the high variation. Male specimens have a range of 84-96 on subcaudal scales, and a range of 284-343 on ventral scales. Whereas in the female specimens, the total range is $83-100$ on subcaudal scales and the total range is 294-341 on ventral scales. The measurement of the morphometric ratio tail length (tl): snout-vent length (SVL) from each population shows that the average ratio of tail length of the male specimens is longer than the average ratio of tail length of female specimens (Table 2). According to Kerfoot [7], ventral scales attach to the cost-cutaneous 


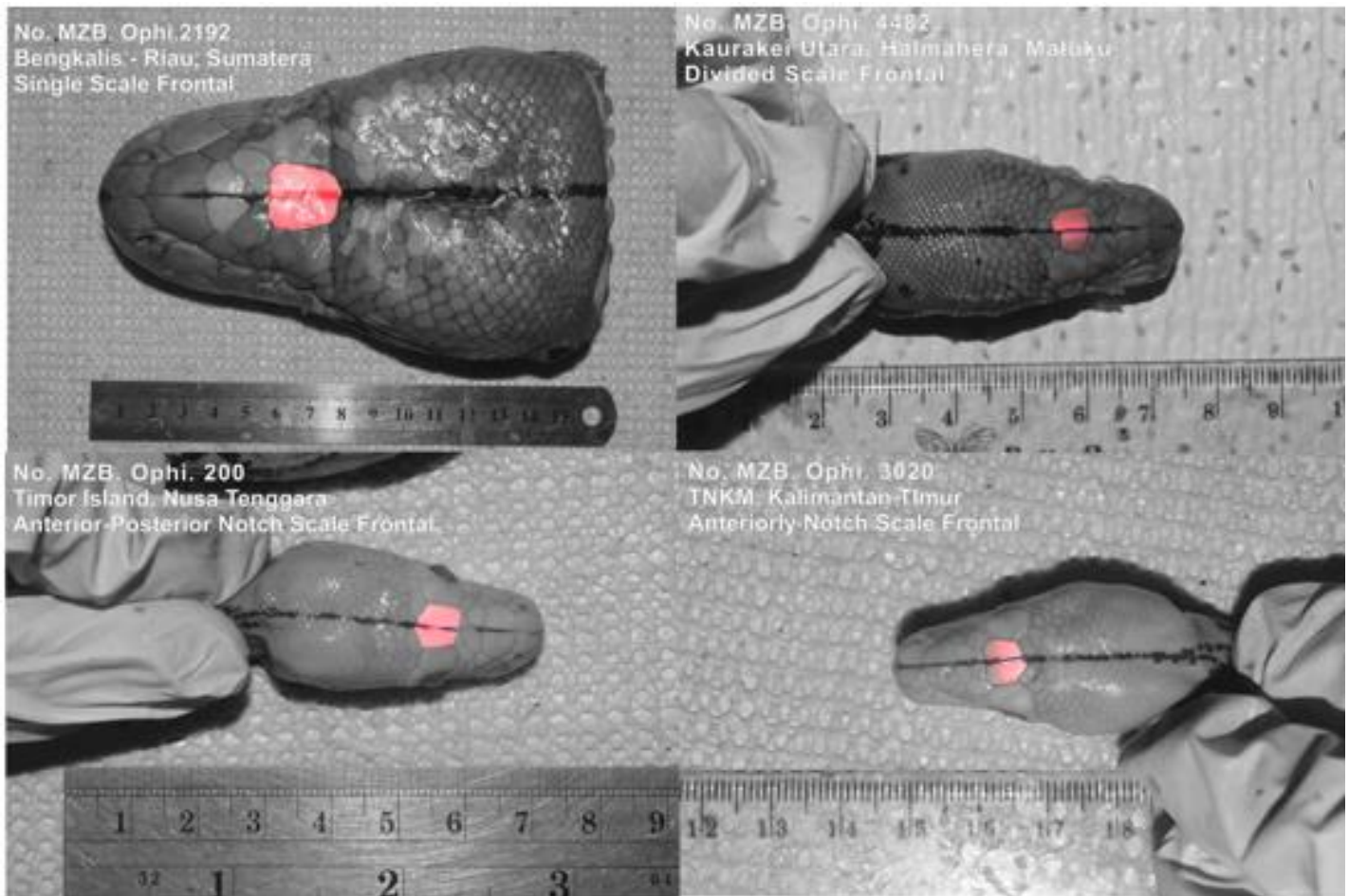

Figure 2. Comparisons of the Frontal Scales of several specimens from various localities, Single (top-left), Divided (top-right), Anterior-Posteriorly Notch (bottom-left), and Anteriorly Notch Frontal Scales (bottom-right) (blue lines indicate the notch).

muscle system that connected to the ribs and vertebrae, so the number of ventral scales reflects the number of vertebrae of the specimens. Individuals with a large number of vertebrae have a possibility to grew longer than individuals who have fewer vertebrae, affecting the number of existing scales.

Differences in the shape and number of frontal scales were also found with the presence of a single, divided, anterior-posteriorly notch, and anteriorly notch frontal scales (Figure 2). It was stated that this variation is due to geographical variations expressed in the form of divided or single scales, different from one region to another [8, 9]. Kluge [10] states that there are several morphological characters that are different from some of the specimens studied in Kalimantan (Borneo) with a variation of almost dividing from posterior, anterior, or both, as well as singles and divided scales. Underwood and Stimson, also Mark Auliya et al. [11, 4] state that the formation of the frontal scales is a type of intraspecific variation. These findings strongly support the existence of intraspecific variations in frontal scales in the population studied, and cannot be categorized as geographic variations based on frontal scales of reticulated python.

\section{The diagnostic characters of $M$. reticulatus sbp. problems}

Prefrontal scales show inconsistencies in a variation of $M$. reticulatus specimens in each population (Table 3). Mark et al. [4], states that there were specific variations in the row of prefrontal scales in each $M$. reticulatus sbp. The species of $M$. reticulatus reticulatus has 2 rows of posterior prefrontal scales with slightly short anterior prefrontal scales, the species of $M$. reticulatus jampeanus has only 1 row of prefrontal posterior scales, with elongated anterior prefrontal scales. Whereas $M$. reticulatus saputrai has 2 rows of posterior prefrontal scales, and slightly enlarged anterior prefrontal scales. Direct observations showed specimens from Sulawesi has 1-row of fragmented posterior prefrontal scales and anterior prefrontal scales on varying size (ID. Number: MZB.Ophi. 1762, MZB.Ophi. 2297, MZB.Ophi. 1558, MZB.Ophi. 3221) resembles M. reticulatus jampeanus. Specimens from Maluku also showed the presence of 1 row posterior prefrontal scales with elongated anterior prefrontal scales (ID. Number: MZB.Ophi. 1951, MZB.Ophi.4481, MZB.Ophi. 4482). However, the specimen observed from Tanahjampea, Kalaotoa, Karompa, 
Table 3. Comparison of dorsal, ventral, prefrontal scales to few literature of M. reticulatus

\begin{tabular}{|c|c|c|c|c|c|}
\hline Population & $\begin{array}{l}\text { Mid- Dorsal } \\
\text { Scale }\end{array}$ & $\begin{array}{l}\text { Ventral } \\
\text { Scales }\end{array}$ & Prefrontal Scales & Resemblance & Source \\
\hline \multirow{3}{*}{$\begin{array}{l}\text { (Sunda land) } \\
\text { M. r. reticulatus } \\
\text { (Selayar) } \\
\text { M r. jampeanus } \\
\text { (TanahJampea) } \\
\text { M. r. saputrai } \\
\end{array}$} & $68-78$ & 304-325 & 2 rows ppf, apf small & - & [4] \\
\hline & $64-68$ & 290-301 & $\begin{array}{l}1 \text { row of ppf, apf slightly } \\
\text { longer than Sunda retic }\end{array}$ & - & [4] \\
\hline & $77-81$ & 330-334 & $\begin{array}{c}2 \text { rows of ppf, apf very } \\
\text { long }\end{array}$ & - & [4] \\
\hline M. reticulatus & $69-79$ & $297-330$ & Variated & $\begin{array}{l}\text { Sulawesi Popula- } \\
\text { tion }\end{array}$ & [13] \\
\hline M. reticulatus & $71-75$ & $300-322$ & - & Java Population & [1] \\
\hline Sumatera $(n=6)$ & $65-76$ & 310-319 & Variated & to $M . r$. reticulatus & This study \\
\hline $\begin{array}{l}\text { Kalimantan } \\
(\mathrm{n}=6)\end{array}$ & $63-74$ & $312-320$ & 2 rows of ppf & to M. r. reticulatus & This study \\
\hline Jawa $(n=4)$ & $\begin{array}{l}61-77 \\
66-90\end{array}$ & 301-320 & $\begin{array}{l}2 \text { rows of ppf } \\
\text { Variated }\end{array}$ & to M. r. reticulatus & $\begin{array}{l}\text { This study } \\
\text { This studv }\end{array}$ \\
\hline Sulawesi $(n=13$ & 66-90 & 294-343 & rinto & to Sulawesi Popula- & ituay \\
\hline Maluku (n=6) & $67-78$ & 284-333 & riated & tion & Inis study \\
\hline NTB $(n=1)$ & 69 & 314 & 2 rows of ppf & to M. r. reticulatus & This study \\
\hline
\end{tabular}

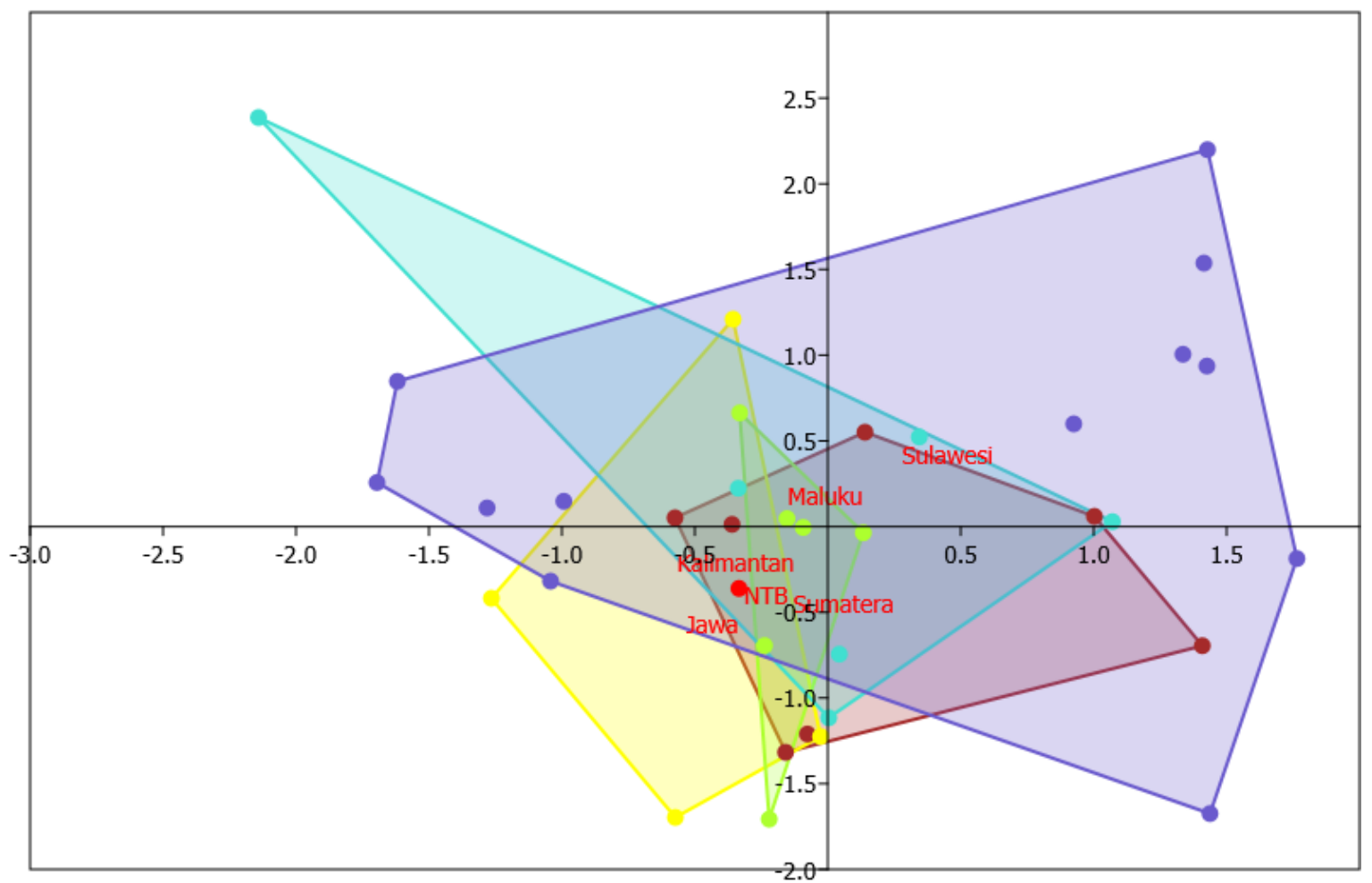

Figure 3. Two-dimensional Scatter plot of 38 M. reticulatus specimens from several population (Sumatra: Brown, Java: Yellow, Kalimantan: Green, NTB: Red, Sulawesi: Blue, and Maluku: Turqoise)

and Madu Island (ID. Number: MZB. Ophi. 3223, MZB. Ophi. 3437, S.Voucher.020, S.Voucher.021, S.Voucher.022, S.Voucher.023) shows the tendency of 1 row posterior prefrontal scales with elongated anterior prefrontal scales, re- sembling the diagnostic character of the $M$. reticulatus jampeanus. In accordance Hanifa et al. [12], which suggest that the Karompa, Kalaotoa, and Madu islands were acting as stepping stones on the dispersal patterns of this species, though 
share similarities to the $M$. reticulatus jampeanus based on morphological and molecular data.

However, these variations are still difficult to distinguish morphologically based on their locality (reticulatus: Greater Sunda-land; saputrai: Selayar; jampeanus: Tanahjampea), given the high morphological variations in these specimens, although phylogenetically have proven to be distinct subspecies [4]. This underlines that the diagnostic character of subspecies based on morphological differences in the prefrontal scales of $M$. reticulatus is still ambiguous and needs deep observation in other characters such as anatomical and morphological features. Specifically, a measurement of prefrontal scales (Anterior-Posterior) are suggested in the future analysis to distinguish this species.

\section{Population grouping of M. reticulatus from In- donesia}

Scatter plots show an overlap in each observed population. The population of Sulawesi has a wide plot width, due to the strong number of Ventral and Dorsal mid characters, where the number of Ventral Scales in the Sulawesi Population and some specimens from Sumatra and Kalimantan have a higher range than other populations.

Based on the analysis, there is no significant differences were found between populations from data on morphometric variations and prominent signs of character variation among the islands. Characters that are owned by a population are still owned by other populations. Geographic isolation has not made any morphological variations that can be used as distinguishing characters. This possible in regards to the varied landscape, habitats, and ecosystems in Indonesia, making it difficult to select a new adaptive character.

\section{Conclusion}

The analysis showed the highly variation on the scale range of anterior prefrontal, posterior prefrontal, frontal, parietal, preocular, postocular, loreal, temporal, upper labial, lower labial, and dorsal scales. Ventral and subcaudal scales in male and female specimens showed highly variation in the scale count, but ratio comparison of tl:SVL length indicated the sexual dimorphism. Anteriorposterior prefrontal and frontal scales show high variation and are difficult to distinguish between each locality at the subspecies level and suggest it to be intra-specific variation. There is no significant grouping were found between populations from data on morphological variations.

\section{Acknowledgment}

We would like to thank Irvan Sidik from Laboratory of Herpetology, Zoology Division, Research Center for Biology, Indonesian Institute of Sciences LIPI, who have been very helpful in discussing and criticizing our research idea. We are also very grateful to Herpetology LIPI Internship team 2018 from various which is Pakuan University, Brawijaya University, also State Islamic University of Maulana Malik Ibrahim Malang, who've helped in the process of documenting the specimens. We would also thank to Maliki Herpetology Society Study Club which provides a place to study and discuss. This study partially supported by The Mohamed bin Zayed Species Conservation Fund, project number 13057088 and IDEA WILD in providing equipment in documenting specimens so the illustration process is supported.

\section{References}

1. De Lang R (2017) The Snakes of Java, Bali and Surrounding Islands. Ohio, Chimaira Edition.

2. Whittaker RJ, Fernández-Palacios JM (2007) Island biogeography: Ecology, evolution, and conservation. Oxford, Oxford University Press.

3. Goin CJ, Goin OB, Zug GR (1978) Introduction to herpetology, 3rd Edition. San Francisco, Freeman WH and Company.

4. Auliya M, Mausfeld P, Schmitz A, Böhme W (2002) Review of Reticulated Python (Python reticulatus Schneider, 1801) with the description of new subspecies from Indonesia. Naturwissenschaften 89 (5): 201 - 213. doi: 10.1007/s00114-002-0320-4.

5. Lillywhite HB, Wray K (2008) Dictionary of herpetology. Florida, Krieger Publishing.

6. Calsbeek R, Knouft JH, Smith TB (2006) Variation in scale number is consistent with ecologically based natural selection acting within and between lizard species. Evolutionary Ecology 20 (4): 377 - 394. doi: 10.1007/s10682-006-0007-y.

7. Kerfoot WC (1970) The Effect of functional changes upon the variability of lizard and snake body scale numbers. Copeia 1970 (2): 252 - 260. doi: 10.2307/1441647.

8. Boulenger GA (1895) Catalogue of snakes in the British Museum (Natural History). London, British Museum (Natural History). Pp 80 - 85. doi: 10.5962/bhl.title.8316.

9. Kopstein F (1926) Reptilien von den Molukken und den benachbarten Inseln. Zoologische Meddelingen 9 (5): 71 - 112. 
10. Kluge AG (1993) Aspidites and the phylogeny of pythonine snakes. Sydney, Australia: Australian Museum. Pp 77.

11. Underwood G, Stimson AF (1990) A Classification of pythons (Serpentes, Pythoninae). Journal of Zoology 221 (4): 565 - 603. doi: 10.1111/j.1469-7998.1990.tb04019.x.

12. Hanifa BF, Nugraha AP, Nanda IF, Daryono BS (2016, June). Phylogenetic analysis of Malayopython reticulatus (Schneider,
1801) from Southern Sulawesi based on morphological and molecular character. In Proceeding of the 4th International Conference on Biological Science: 18-19 September 2015, Yogyakarta. Edited by Setyobudi RH, Nuringtyas TR, Adinurani PG. AIP Publishing. doi: 10.1063/1.4953482.

13. Rooij ND (1915) The reptiles of the Indo-Australian archipelago (Vol. 1). Leiden, Brill Archive. Pp 20-22. 